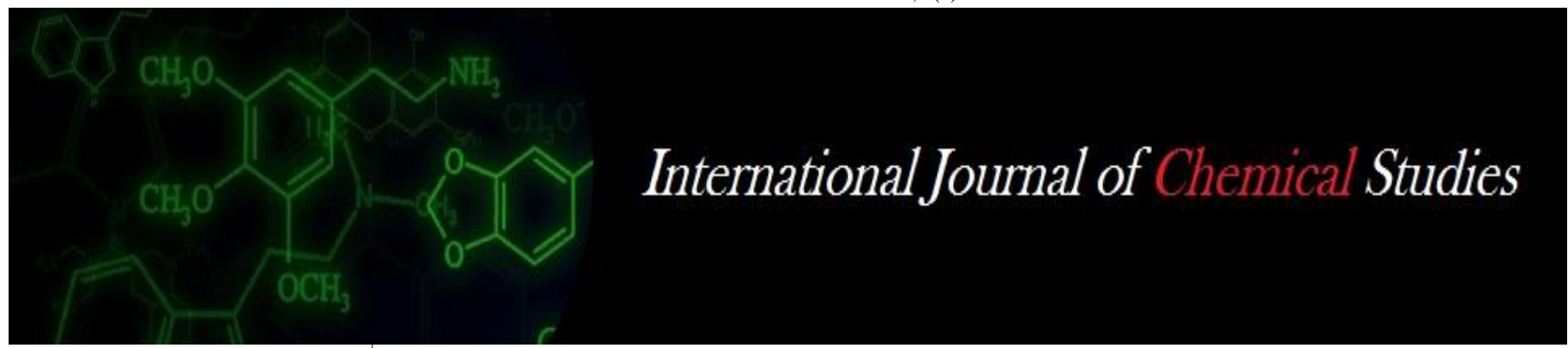

P-ISSN: 2349-8528

E-ISSN: 2321-4902

www.chemijournal.com

IJCS 2020; 8(2): 2352-2355

(C) 2020 IJCS

Received: 04-01-2020

Accepted: 06-02-2020

N Pandey

Department of Plant Pathology, College of Horticulture, VCSG

UUHF, Bharsar Pauri Garhwal,

Uttarakhand, India

S Ravi

Department of Plant Pathology, College of Horticulture, VCSG

UUHF, Bharsar Pauri Garhwal,

Uttarakhand, India
Corresponding Author:

N Pandey

Department of Plant Pathology, College of Horticulture, VCSG

UUHF, Bharsar Pauri Garhwal,

Uttarakhand, India

\section{Effect of biocontrol agents and fungicides against anthracnose of French bean caused by Colletotrichum lindemuthianum (Sacc. and Magn.) in mid-hill of Garhwal Himalaya}

\section{N Pandey and S Ravi}

DOI: https://doi.org/10.22271/chemi.2020.v8.i2aj.9101

Abstract

Evaluated the efficacy of different bioagents and fungicides used as seed treatment and foliar spray, tested alone and in the combination. Ten treatments including control were tested against French bean anthracnose caused by Colletotrichum lindemuthianum. Among all these treatments minimum per cent disease incidence (PDI) and per cent severity index (PSI) were recorded in alone Carbendazim $(8.33,11.66$ and $18.30 \%)$ and in combination Carbendazim $+P$. fluorescens $(16.00,26.33$ and $39.33 \%)$ at 55, 75 and 95 DAS. Minimum (PSI) at 55, 75 and 95 DAS were recorded in alone i.e. $(4.58,7.41$ and $10.11 \%)$ and in combination $(9.11,16.54$ and $21.00 \%)$. Highly PDI and PSI had observed in the control compare to all other treatments.

Keywords: French bean, anthracnose, Colletotrichum lindemuthianum, bioagents, fungicides, PDI, PSI

\section{Introduction}

French bean (Phaseolus vulgaris L.) is an important legume crop in tropical regions. It is noticed as a good source of proteins and vitamins Mohammed et al. (2013) ${ }^{[10]}$. This crop is also known as common bean and Rajmash. Bean is used as a pulse as well as a green vegetable. French bean is mainly cultivated in Himanchal Pradesh, hills of Mahabaleshwar, Jammu \& Kashmir Maibam et al. (2015) ${ }^{[9]}$. Bean crop is affected by many diseases like common bacterial blight (Xanthomonas campestris pv. phaseoli), Rust (Uromyces appendiculatus), Anthracnose (Colletotrichum lindemuthianum (Sacc. and Magnus) Amin et al. (2014) ${ }^{[3]}$. The fungus Colletotrichum lindemuthianum is often present in or on the seed of the infected pods. Infected pods may show yellowish to brown sunken lesion. Agrios (2005) ${ }^{[2]}$. Among all anthracnose which is caused by the fungus Colletotrichum lindemuthianum (Sacc. and Magnus) causes severe economic loss in French bean. Loss due to anthracnose is greater in temperate region as compare to tropics. Anthracnose is a seed borne disease of bean and infested soil and debris are primary source of inoculum Mohammed et al. (2013) ${ }^{[10]}$. Due to anthracnose $100 \%$ yield reduction was recorded by Fernandez et al. (2000) ${ }^{[8]}$. Anthracnose disease is favoured by high temperature $\left(19-25^{\circ} \mathrm{C}\right)$ high humidity $(<70 \%)$ Aggarwal et al. (2017) ${ }^{[1]}$. The first step for the management of disease is to reduce the pathogen inoculum from the field. Management practices to minimize the seed borne infection by biological control and chemical control methods. Foliar spray with Carbendazim and Hexaconazole were effective to reduce disease, observed by Mohammed et al. (2013) ${ }^{[10]}$. In biocontrol agents Trichoderma harzianum and Pseudomonas fluorescence were effective and reported by Padder et al. (2010) ${ }^{[11]}$.

\section{Materials and Methods}

Field experiment was conducted at Vegetable Research and Demonstration Block, College of Horticulture, Bharsar during 2017. About $58 \mathrm{~km}$ away from Pauri city, situated at an altitude of 1900 meters above mean sea level. Geographical position of experimental site lies between latitude $29^{\circ}$ North and of $78^{\circ}$ East longitudes under western himalayan zone of Uttarakhand. 
Evaluation of treatments: Ten treatments were obeserved under the field condition namely; Alone Hexaconazole $(5 \%$ SC) $1 \mathrm{ml} / \mathrm{L}$, Captan (50\% WP) $2.5 \mathrm{gm} / \mathrm{kg}$ seed, Carbendazim (50\% WP) $2.5 \mathrm{gm} / \mathrm{kg}$ seed, Bacillus ceresus@ (5gm/ $\mathrm{kg}$ of seed), Trichoderma harzianum (5 gm/ $/ \mathrm{kg}$ of seed) and Pseudomonas fluorescens $(5 \mathrm{gm} / \mathrm{kg}$ of seed).Three combination treatments viz., Hexaconazole + Bacillus ceresus @ $0.5 \mathrm{ml} / \mathrm{L}+1.25 \mathrm{gm} / \mathrm{kg}$ seed, Captan + Trichoderma harzianum @ 1.25 gm/L +2.5 gm/kg seed and Carbendazim + Pseudomonas fluorescens@ $1.25 \mathrm{gm} / \mathrm{L}+2.5 \mathrm{gm} / \mathrm{kg}$ seed.

Seed treatment have done with two bioagents $P$. fluorescence and B. ceresus @ (5 gm/ $\mathrm{kg}$ of seed) and one contact fungicide Captan $(2.5 \mathrm{gm} / \mathrm{kg}$ seed $)$ were soaked in $1 \mathrm{~L}$ of water for 24 hours before sowing. All the treatments were treated separately overnight before sowing. Seed treatments have done, 24 seeds for each plot Amin et al. (2014) ${ }^{[3]}$.

Foliar spray have done namely Carbendazim $2.5 \mathrm{gm} / \mathrm{kg}$ seed, Captan $2.5 \mathrm{gm} / \mathrm{kg}$ seed and Hexaconazole $1 \mathrm{ml} / \mathrm{L}$. Contender variety of bean was used for the experiment and seeds were sown in the beds with Randomized Complete Block Design (RCBD) with three replications in plot size of $1.35 \mathrm{~m} \times 1.20 \mathrm{~m}$ (Chaudhary and Dhaka, 2003) ${ }^{[6]}$. The plant was spaced at 45 $\mathrm{cm} \times 15 \mathrm{~cm}$ and twenty four plants per plot.

\section{Per cent disease incidence (PDI)}

PDI was calculated with the help of the formula which is given by Wheeler (1969) ${ }^{[14]}$. It was calculated at 55,75 and 95 DAS after sowing from five randomly tagged plants.

Per cent disease incidence $=\frac{\text { Number of infected pods }}{\text { Total number of pods examined }} \times 100$

Per cent severity index (PSI): PSI was calculated by using standard scale (1-9) of CIAT, from five tagged plants at 55, 75 and 95 DAS then it was calculated by help of the formula given by Wheeler (1969) ${ }^{[14]}$.

Per cent severity index $=\frac{\text { Sum of all numerical rating } \times 100}{\text { No. of plant scored } \times \text { maximum score on scale }}$

The rating scale was given by CIAT (1987) ${ }^{[7]}$.

\begin{tabular}{|c|c|}
\hline Rating scale & Per cent infection \\
\hline 1 & No infection \\
\hline 3 & Up to $1 \%$ pod surface area \\
\hline 5 & Up to $5 \%$ pod surface area \\
\hline 7 & Up to $10 \%$ pod surface area \\
\hline 9 & More than $25 \%$ pod surface area \\
\hline
\end{tabular}

The data had obtained and analyzed by using simple randomized complete block design (RCBD) and performed with the help of OPSTAT.

\section{Results and Discussion}

Present investigation was carried out to evaluate ten treatments have been observed.

PDI at 55, 75 and 95 days after sowing (DAS): The observation had recorded in (Table 1 and Fig.1) showed significant differences between treatments and control. Among these alone Carbendazim at (55, 75 and 95 DAS) the most effective, minimum anthracnose per cent disease incidence was recorded $(8.33,11.66$ and $18.30 \%)$ and maximum in Bacillus ceresus ie. (34.32, 49.53 and 59.05\%). In combination minimum in Carbendazim $+P$. fluorescens (16.00, 26.33 and 39.33) and maximum in Captan $+T$. harzianum $(21.28,34.33$ and 50.62\%) and maximum PDI was recorded in control comparison to all treatments.
Mohammed et al. (2013) ${ }^{[10]}$ also observed that foliar spray with Carbendazim is effective in reduce disease in field condition and they found i.e. (18.9 and 16.1\%) at 52 and 60 DAS. Vivekanand et al. (2018) ${ }^{[13]}$ also found effective and low per cent disease index (PDI) at 75, 90 and 105 DAT, in alone Mancozeb and Captan; in combination T. harzianum + Captan and followed by $P$. fluorescens + Carbendazim against chilli anthracnose (Colletotrichum capsici). Chavan and Suryawanshi (2014) ${ }^{[5]}$ found the fungicides i.e. Carbendazim $(0.1 \%)$ and Mancozeb $(0.2 \%)$ against soyabean anthracnose (Colletotrichum truncatum) and among these, Carbendazim $(0.1 \%)$ was found most effective in the reduction of disease intensity with highest yield i.e. $2525 \mathrm{~kg} / \mathrm{ha}$.

Table 1: Effect of treatments on per cent disease incidence (PDI) at 55,75 and 95 days after sowing (DAS) at different doses against $C$. lindemuthianum

\begin{tabular}{|c|c|c|c|}
\hline \multirow{2}{*}{ Treatments } & \multicolumn{3}{|c|}{ PDI } \\
\cline { 2 - 4 } & 55 DAS & 75 DAS & 95 DAS \\
\hline \multirow{2}{*}{ Control } & 38.27 & 51.19 & 70.72 \\
& $(57.22)$ & $(45.66)$ & $(57.22)$ \\
\hline \multirow{2}{*}{ Hexaconazole } & 11.50 & 15.26 & 23.07 \\
& $(25.95)$ & $(22.96)$ & $(28.68)$ \\
\hline \multirow{2}{*}{ Captan } & 27.00 & 38.33 & 55.66 \\
& $(45.33)$ & $(38.23)$ & $(48.23)$ \\
\hline \multirow{2}{*}{ Carbendazim } & 8.33 & 11.66 & 18.30 \\
& $(23.81)$ & $(19.93)$ & $(25.31)$ \\
\hline \multirow{2}{*}{ Bacillus ceresus } & 34.32 & 49.53 & 59.05 \\
& $(50.19)$ & $(44.71)$ & $(50.19)$ \\
\hline \multirow{2}{*}{ Trichoderma harzianum } & 25.33 & 38.52 & 53.66 \\
& $(48.23)$ & $(38.34)$ & $(47.08)$ \\
\hline \multirow{2}{*}{ Pseudomonas fluorescens } & 30.00 & 40.33 & 57.22 \\
& $(47.08)$ & $(39.40)$ & $(49.13)$ \\
\hline \multirow{2}{*}{ Hexaconazole + B. ceresus } & 20.71 & 32.33 & 48.85 \\
& $(44.31)$ & $(34.64)$ & $(44.31)$ \\
\hline \multirow{2}{*}{ Captan+T. harzianum } & 21.28 & 34.33 & 50.62 \\
& $(49.10)$ & $(35.83)$ & $(45.33)$ \\
\hline \multirow{2}{*}{ Carbendazim + P. fluorescens } & 16.00 & 26.33 & 39.33 \\
& $(38.81)$ & $(30.89)$ & $(36.44)$ \\
\hline CD (p=0.05) & 4.24 & 3.88 & 4.02 \\
\hline
\end{tabular}

( ) -Value in parentheses are angular transformed

PDI - Per cent disease incidence, DAS- Days after sowing

PSI at 55, 75 and 95 days after sowing (DAS): The observation had recorded in (Table 2 and Fig. 2) showed that minimum severity index, among these alone Carbendazim at (55, 75 and 95 DAS) i.e. (4.58,7.41 and 10.11\%) and maximum in B. ceresus (18.24 and $38.66 \%) 55$ and 95 DAS, in $T$. harzianum was recorded $(28.52 \%)$ at 75 DAS. In combination minimum was recorded (Carbendazim+ $P$. fluorescens) at (55, 75 and 95 DAS) ie. (9.11,16.54 and $21.00 \%$ ) and maximum was recorded in (Captan $+T$. harzianum) i.e. (12.33 and 18.51) at 55 and 75 DAS and other way at 95 DAS i.e. Hexaconazole + B.ceresus $(25.74 \%)$ and maximum PSI was recorded in control comparison to all treatments.

Mohammed et al. (2013) ${ }^{[10]}$ also observed the per cent severity index (PSI) ie. (13.3\% and 19.0\%) when foliar spray with Carbendazim against anthracnose of common bean (Colletotrichum lindemuthianum). Bhardwaj and Thakur (1991) ${ }^{[4]}$ found that Carbendazim $(0.1 \%)$ against anthracnose of urdbean was found effective to reduce disease severity. Vivekanand et al. (2018) ${ }^{[13]}$ also found effective and low disease fruit rot severity, in alone Captan and Mancozeb; in combination $T$. harzianum + Captan and followed by $P$. fluorescens + Carbendazim against chilli anthracnose (Colletotrichum capsici). Sileshi et al. (2014) ${ }^{[12]}$ observed the 
severity and incidence of anthracnose increased with time from the 39 DAS onwards. Disease incidence data showed the highly significant difference $(P<0.01)$ among treatment at (39 and 67 DAS). There were no significant difference in disease incidence among treatments at (95 DAS). Bioagents, treated with $T$. viride and $P$. fluorescens showed the least disease incidence $(38.5 \%)$ at the plots initial date (39 DAS) disease assessments, $P$. fluorescence showed the least disease incidence at 39, 53, 67 and 81 DAS.

Table 2: Effect of treatments on per cent severity index (PSI) at 55, 75 and 95 days after sowing (DAS) at different doses against $C$. lindemuthianum

\begin{tabular}{|c|c|c|c|}
\hline \multirow{2}{*}{ Treatments } & \multicolumn{3}{|c|}{ PSI } \\
\cline { 2 - 4 } & 55 DAS & 75 DAS & 95 DAS \\
\hline Control & $22.33(28.16)$ & $29.09(32.61)$ & $42.77(40.82)$ \\
\hline Hexaconazole & $5.62(13.71)$ & $8.52(16.93)$ & $21.18(20.34)$ \\
\hline Captan & $13.33(21.40)$ & $19.87(26.43)$ & $32.54(34.76)$ \\
\hline Carbendazim & $4.58(12.34)$ & $7.41(15.74)$ & $10.11(18.52)$ \\
\hline Bacillus ceresus & $18.24(25.26)$ & $28.51(32.26)$ & $38.66(38.41)$ \\
\hline Trichoderma harzianum & $12.75(20.79)$ & $28.52(27.59)$ & $31.33(34.02)$ \\
\hline Pseudomonas fluorescens & $16.49(23.92)$ & $26.85(31.19)$ & $34.18(35.75)$ \\
\hline Hexaconazole + B.ceresus & $10.00(18.41)$ & $18.43(25.39)$ & $25.74(30.45)$ \\
\hline Captan + T. harzianum & $12.33(20.46)$ & $18.51(25.43)$ & $24.63(32.32)$ \\
\hline Carbendazim + P. fluorescens & $9.11(17.54)$ & $16.54(23.89)$ & $21.00(27.21)$ \\
\hline C.D $(\mathrm{p}=0.05)$ & 3.01 & 4.31 & 4.22 \\
\hline
\end{tabular}

( ) -Value in parentheses are angular transformed

PSI - Per cent severity index; DAS- Days after sowing

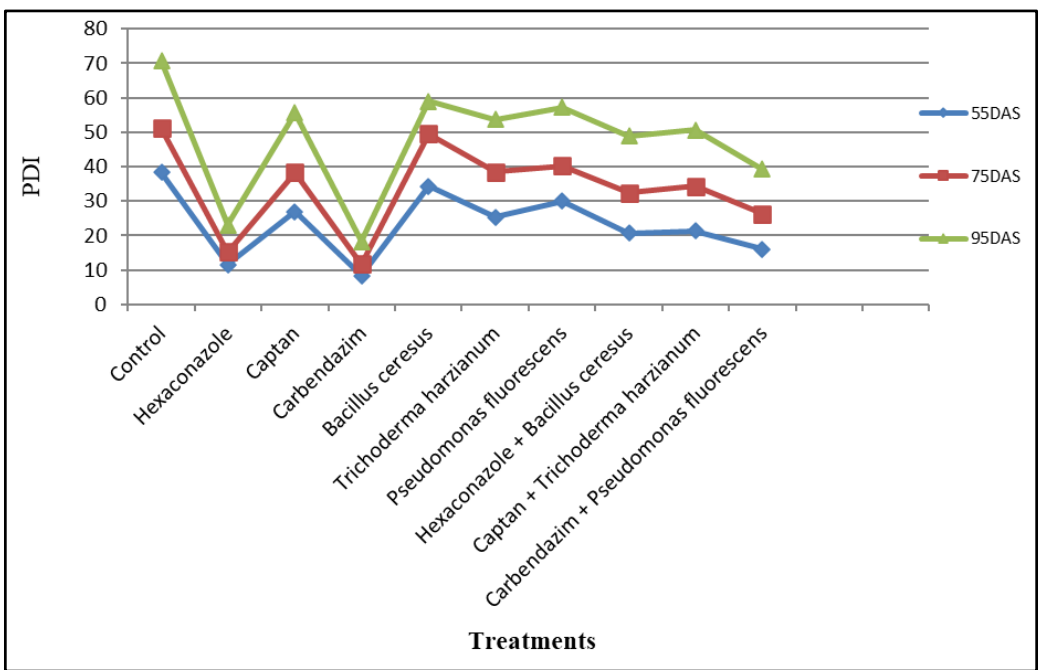

Fig 1: Effect of different treatments on Per cent disease incidence at 55, 75 and 95 DAS of $C$. lindemuthianum

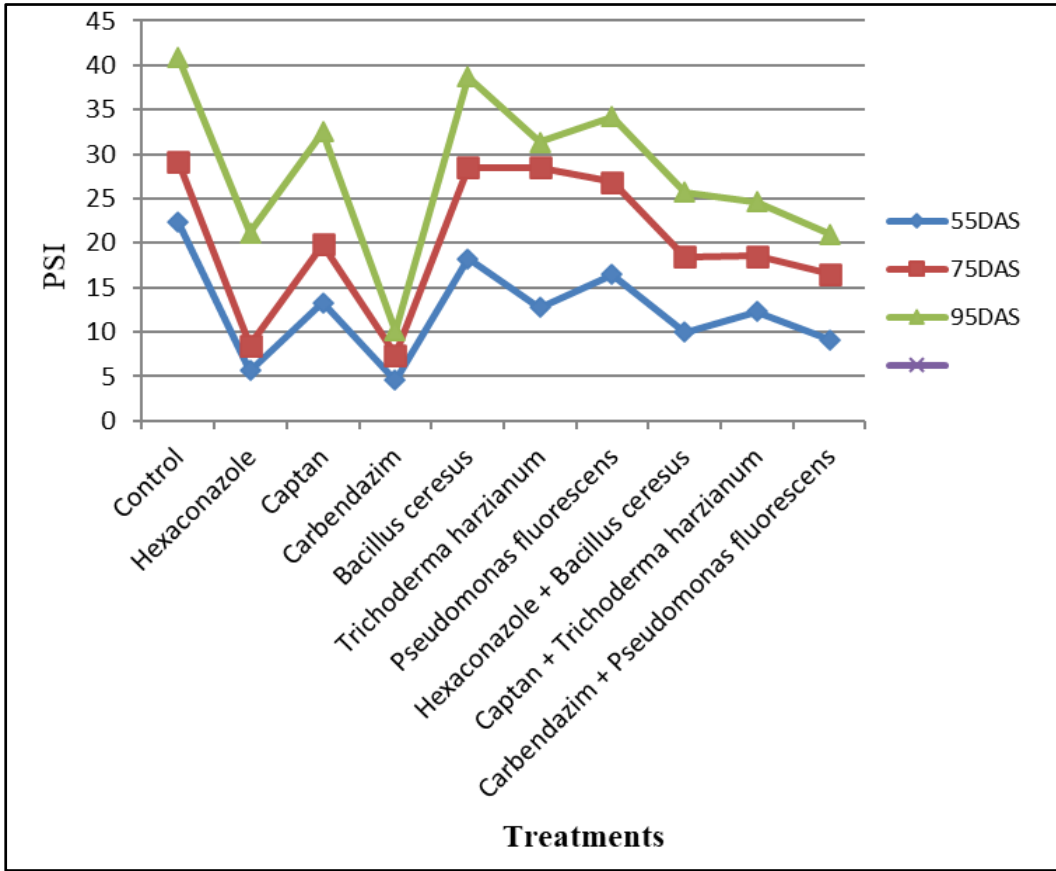

Fig 2: Effect of different treatments on Per cent severity index at 55, 75 and 95 DAS against $C$. lindemuthianum 


\section{Conclusion}

Management of French bean anthracnose in Bharsar condition. Our study was based on fungicides and bioagents showed that, among all these treatments found minimum per cent disease incidence (PDI) and per cent severity index (PSI), alone Carbendazim and in combination Carbendazim + $P$. fluorescens most effective at 55, 75 and 95 DAS. In other way maximum (PDI) and (PSI) were observed in control comparison to all treatments, also above mentioned treatments gave higher yield.

\section{Acknowledgement}

The authors wish to thank the OIC, Vegetable Research and Demonstration Block, College of Horticulture, VCSG UUHF, Bharsar (Pauri Garhwal) Uttarakhand.

\section{References}

1. Aggarwal SK, Mali BL, Rajput LS, Choudhary M. Epidemiology of anthracnose of black gram caused by Colletotrichum lindemuthianum. International Journal of Agriculture Sciences. 2017; 2(9):3656-3657.

2. Agrios GN. Plant Pathology. $5^{\text {th }}$ edition. Dept of Plant Pathology, University of Florida. Academic Press. An imprint of Elsevier, 2005, 487.

3. Amin M, Teshele J, Tesfay A. Evaluation of bioagents seed treatment against Colletotrichum lindemuthianum, in Haricot bean anthracnose under field condition. Res. Plant Sci. 2014; 2(1):22-26.

4. Bhardwaj CI, Thakur DR. Efficacy and economics of fungicides spray schedules for control of leaf spots and pod blights in Urdbean. Indian Phytopathology. 1991; 44(4):470-475.

5. Chavan SS, Suryawanshi AP. In vivo evaluation of fungicides, botanicals and bioagents against $C$. truncatum causing anthracnose/pod blight of soyabean. The bioscan. 2014; 9(4):1581-1585.

6. Choudhary BR, Dhaka RS. Vegetable Crops Production Technology. 1 th Edition. Kalyani Publication. 2003, 86.

7. CIAT. Anthracnose standard system for the evaluation of bean germplasm in CIAT, Coli, Colombia. The genera of fungi. Hafner, New York. 496 PP. Colombia. Common bacterial blight in Phaseolus bean. Plant Pathology. 1987; 45:1126-1133.

8. Fernandez M, Casares A, Rodriguez R, Fueyo M. Bean germplasm evaluation for anthracnose resistance and characterization of agronomic traits. A new Physiological Stain of Colletotrichum lindemuthianum infecting Phaseolus vulgaris L. in Spain. Euphytica. 2000; 114:143-149.

9. Maibam N, Chandra S, Baiswar P, Majumder D, Saikia $\mathrm{K}$. Host plant resistance and yield loss due to anthracnose caused by Colletotrichum lindemuthianum in french bean (Phaseolus vulgaris). Indian Journal of Hill Farming. 2015; 28(1):14-18.

10. Mohammed A, Ayalew A, Dechassa N. Effect of integrated management of bean anthracnose (Colletotrichum lindemuthianum) through soil solarization and fungicides application on epidemics of the disease and seed health in haraghe highland, Ethiopia. Journal of Plant Pathology and Microbiology. 2013; 4:6.

11. Padder BA, Sharma PN, Kapil R, Pathania A, Sharma OP. Evaluation of bioagents and biopesticides against Colletotrichum lindemuthianum and its integrated management in common bean. Not. Sci. Biol. 2010; 2(3):72-76.

12. Sileshi F, Mohammed A, Selvaraj T, Nageri M. Field management of anthracnose (Colletotrichum lindemuthianum) in Common bean through foliar spray fungicides and seed treatment Bioagents. Star Journal. 2014; 3:19-25.

13. Vivekanand, Ravi S, Mishra RC, Bahuguna P. Evaluation of various management techniques against chilli anthracnose, Colletotrichum capsici (Sydow) in Western Himalayan Zone of Uttarakhand. Int. J. Pure App. Biosci. 2018; 6(2):861-867.

14. Wheeler BEJ. An Introduction to Plant Diseases. John Willey and Sons Ltd. 1969, 301 